\title{
CAN GOD'S GOODNESS SAVE THE DIVINE COMMAND THEORY FROM EUTHYPHRO?
}

\author{
JEREMY KOONS \\ Georgetown University School of Foreign Service in Qatar
}

\begin{abstract}
Recent defenders of the divine command theory like Adams and Alston have confronted the Euthyphro dilemma by arguing that although God's commands make right actions right, God is morally perfect and hence would never issue unjust or immoral commandments. On their view, God's nature is the standard of moral goodness, and God's commands are the source of all obligation. I argue that this view of divine goodness fails because it strips God's nature of any features that would make His goodness intelligible. An adequate solution to the Euthyphro dilemma may require that God be constrained by a standard of goodness that is external to Himself - itself a problematic proposal for many theists.
\end{abstract}

The Euthyphro dilemma is often thought to present a fatal problem for the divine command theory (aka theological voluntarism). Are right acts commanded by God because they are right, or are they right because they are commanded by God? If the former, then there is a standard of right and wrong independent of God's commands; God's commands are not relevant in determining the content of morality. This option seems to compromise God's sovereignty in an important way. But the second horn of the dilemma presents seemingly insurmountable problems, as well. First, if God's commands make right actions right, and there is no standard of morality independent of God's commands, then that seems to make morality arbitrary. Thus, murder is not wrong because it harms someone unjustly, but merely because God forbids it; there is (it seems) no good connection between reason and the wrongness of murder. Furthermore, if God commanded us to torture an innocent child to death, then torturing an innocent child to death would (it seems) be 
morally obligatory. Most of us find these consequences absurd, and a sufficient reason for rejecting divine command theory.

Since the first horn of the dilemma represents moral obligations as being independent of God's commands, a divine command theorist must somehow tackle the second horn of the dilemma. A tempting strategy is to say that while torturing an innocent child to death would be obligatory if God commanded this, God would never command such a thing because such a command would be contrary to His good and loving nature. However, such a move seems incompatible with divine command theory: it suggests that God is bound by moral requirements (He cannot command torturing an innocent child to death because such a command would be immoral), whereas divine command theory claims that God is the source of all moral requirements. ${ }^{1}$

However, a number of divine command theorists have argued recently that this move is legitimate. These theorists argue that divine command theory is not a theory of all moral values; it is merely a theory of moral obligation. ${ }^{2}$ We can still say that God is good, as long as we do not construe this goodness in terms of God doing what He ought to do. 'Oughts' (which apply to finite beings such as us humans) are in turn constituted by the commands of God. And since He is good, He would never command torturing an innocent child to death, and so the second horn of our Euthyphro dilemma is defused. Thus, Wierenga writes, "bringing about a foully unjust state of affairs [S]...is incompatible with being loving and just; so then is commanding someone else to bring S about. Accordingly, since these are essential features of God's character, they preclude his commanding that someone bring about $S$ in any possible world." ${ }^{3}$ Further, God's nature provides God with adequate reason to issue the particular commands He does, alleviating the arbitrariness worry about divine command theory: this move seems to restore the relation between moral reasons and God's commands.

\section{WHAT IS GOD'S GOODNESS?}

Wherein does God's goodness consist? Alston writes that God's goodness supervenes on His lovingness and other such traits. ${ }^{4}$ A natural question

\footnotetext{
${ }^{1}$ For a particularly lucid statement of this objection, see Hooker (2001).

${ }^{2}$ See, for example, Wierenga (1989), Adams (1999), Alston (2002), and Quinn (2006).

${ }^{3}$ Wierenga (1989), p. 221.

${ }^{4}$ Alston (2002).
} 
arises as to the relation between the traits that God manifests qua supremely good being and His goodness: are qualities like being merciful and loving traits of God because they are good, or are they good because they are traits of God? Simply put: why is it good to be loving? Is being loving independently good, apart from its being one of God's traits? Or is it good merely because God is loving? This is not simply another iteration of the Euthyphro problem - is God loving because being loving is good or is being loving good because God is loving? - because the horns of this dilemma have somewhat different outcomes. In the original Euthyphro dilemma, the worry about the second horn of the dilemma was that if right acts were right because God commanded them, then that made morality arbitrary - torture for fun is immoral, but God did not have a good (i.e., moral) reason for forbidding such torture, and there would have been nothing immoral about his commanding torture for fun. But the divine command theorist is not saying that the relation between the goodness of being loving and the fact of God's lovingness is so arbitrary as that: it is not the mere fact of God's being loving that makes it good to be loving. Rather, it is the fact that God is loving, combined with the fact that God is supremely good that makes being loving good. As Alston puts the point,

We can think of God himself, the individual being, as the supreme standard of goodness...Lovingness is good (a good-making feature, that on which goodness is supervenient) not because of the Platonic existence of a general principle or fact to the effect that lovingness is good, but because God, the supreme standard of goodness, is loving. Goodness supervenes on every feature of God, not because some general principles are true but just because they are features of God. ${ }^{5}$

So God is good (indeed, He is the supreme standard of goodness), and that is why His being loving makes being loving good. So it seems initially that the second option involves no arbitrariness: being loving is good because it is a trait of God, who is supremely good. (We will revisit this initial conclusion later, though.)

Notice, however, the order of explanation here. God is not good because $\mathrm{He}$ is loving. That would imply a standard of goodness independent of God, which divine command theorists like Alston and Adams must deny. They claim that God is the standard of goodness, that

${ }^{5}$ Alston (2002), pp. 291-2. 
whatever properties (such as being loving) God has are good in virtue of God's essential goodness. Thus, God's goodness must be logically prior to the goodness of God's mercy, justice, lovingness, and so on. Indeed, Adams speculates that in a possible world with no God, nothing would be excellent or good, not even character traits we normally consider good (like being loving). Adams writes,

If there is a God that satisfies [the] conditions imposed by our concepts [of the Good], we might say, then excellence is the property of faithfully imaging such a God...In worlds where no such God exists, nothing would have that property, and therefore nothing would be excellent. But beings like us in such a world might have a concept subjectively indistinguishable from our concept of excellence, and there might be an objective property that corresponded to it well enough, and in a sufficiently salient way, to be the property signified by it, though it would not be the property that we in fact signify by 'excellent?'

Wainwright notes that an apparent consequence of Adams's theory is that if there is a possible world where there is no God, and no plausible alternative candidate for the role of the Supreme Good, then assuming that 'Adams's account of the semantics of 'good' is more or less correct, then the term 'good' doesn't pick out a real property in those worlds; the concept of good will be as empty in those worlds as the concept of phlogiston is in ours". In those worlds, being (e.g.) loving is not good. God's goodness is logically prior to the goodness of such traits, and their goodness depends on and is parasitic on the prior goodness of God. ${ }^{8}$

\section{IS THIS VIEW OF GOD'S GOODNESS COHERENT?}

Does this picture of God's goodness make any sense?" (Alston will be our primary interlocutor since he, more than others, has grappled with the problematic implications of this conception of God's goodness.)

\footnotetext{
${ }^{6}$ Adams (1999), p. 46.

${ }^{7}$ Wainwright (2005), p. 95.

${ }^{8}$ Of the authors under discussion, Alston alone disputes this; but I will argue below that Alston endorses incompatible theses about the relation between God's goodness and the goodness of traits like mercy and justice.

9 This view of God's goodness has had its critics; see, in particular, Morriston (2001) and (2009) and Kowalski (2010). I will be approaching the issue from a somewhat different direction than these authors, trying to tease out whether the conception of God's goodness proposed by Adams, Alston, and their allies is metaphysically coherent.
} 
Certainly, it seems to reverse the intuitive order of explanation between something's goodness and the other properties it exemplifies. As Wes Morriston writes in a penetrating critique of Alston's view,

Is God good because He has these good-making properties? Or are they good-making because God has them? The first alternative seems, intuitively, to be the right one. Why should it make any difference to the good-makingness of compassion, say, if there is (or isn't) a supremely compassionate God?10

This is puzzling, but there is a deeper problem confronting the Adams/Alston account. Adams and Alston claim that God is good, but given the above order of explanation, they are debarred from pointing to any feature in virtue of which God is good. (Alston denies this, but I will argue that he cannot do so coherently; we will return to this point later.) Rather, those features themselves are good in virtue of belonging to God (who is good). Then what does it mean to say that God is good? It doesn't mean that He is just, or loving - His goodness is prior to the goodness of these features. Alston and Adams must say this, else admit that there is a standard of goodness independent of God. So the property of goodness, as it applies to God, is undifferentiated, a 'featureless property'. As Kowalski summarizes the problem,

How should we understand God, a particular concrete being, serving as the standard of goodness? In virtue of what does God so serve? In order to avoid grounding God's goodness, as the Platonist would, in truths that do not depend on God, it seems that God must somehow serve as the supreme standard of goodness apart from the properties $\mathrm{He}$ in fact possesses. It thus seems that God, qua bare particular, serves as the ultimate standard for moral goodness. ${ }^{11}$

The problem is this: actions and agents instantiate morally thin properties (rightness, goodness, etc.) in virtue of the morally thick properties these actions and agents instantiate. An action is not good simpliciter; it is good because it represents an act of charity, or a repaying of a debt, or something else. It is good in virtue of something else. Similar comments apply to the goodness of agents. The benefit of moving to the level of the descriptively thin is that it can be silent as to what this 'something else' is - as Elstein and Hurka write, “The mark of a thin

\footnotetext{
${ }^{10}$ Morriston (2009), p. 253.

${ }^{11}$ Kowalski (forthcoming), p. 5.
} 
concept like 'right' is that it says nothing about what other properties an item falling under it has"12 - but let us not take this silence to be metaphysical. We cannot use these thin concepts without remembering that at bottom they are paper currency whose value depends on a reserve of thick virtues.

\section{ALSTON'S PARTICULARISM}

Alston has addressed the worry that this strategy of making God the standard of moral goodness renders God's goodness unintelligible. Alston writes:

Note that on this view we are not debarred from saying what is supremely good about God. God is not good, qua bare particular or undifferentiated thisness. God is good by virtue of being loving, just, merciful and so on. ${ }^{13}$

Does this answer the objection? It is unclear. For mark how the passage continues:

Where this view differs from its alternative is in the answer to the question, 'By virtue of what are these features of God good-making features?' The answer given by this view is: 'By virtue of being features of God. ${ }^{14}$

So Alston is explicit here that these features are only good because God possesses them. As Alston writes earlier in his essay,

Lovingness is good (is a good-making feature, that on which goodness is supervenient) not because of the Platonic existence of a general principle or fact to the effect that lovingness is good, but because God, the supreme standard of goodness, is loving. Goodness supervenes on every feature of God, not because some general principles are true but just because they are features of God. ${ }^{15}$

So we have a puzzle. The first passage indicates that God is good because of these good-making traits (such as lovingness, mercy, and so on). But the second and third quotes reverse the order of explanation: they say not that God is good because He possesses these traits, but that these traits are good-making because God possesses them. What is the correct order of explanation? Can Alston have it both ways? I will argue that he

\footnotetext{
${ }^{12}$ Elstein and Hurka (2009), p. 516.

${ }^{13}$ Alston (2002), p. 292.

${ }^{14}$ Alston (2002), p. 292.

${ }^{15}$ Alston (2002), pp. 291-2, emphasis added.
} 
cannot; Alston's particularism requires that God's goodness be logically prior to the goodness of the moral virtues. And we will see that this view is incoherent; it makes God's goodness unintelligible.

Alston distinguishes between

(a) 'Platonic' predicates, the criterion for the application of which is a general 'essence' or 'Idea' that can be specified in purely general terms, and (b) 'particularist' predicates, the criterion for the application of which makes essential reference to one or more individuals. ${ }^{16}$

Alston suggests 'triangle' as a good paradigm of the former kind. Alston's theory of the good is particularist: a particular individual (God) is the standard of goodness. Alston suggests an illuminating analogy:

A sub-type closer to our present concern is the much-discussed 'meter'. Let's say that what makes a certain length a meter is its equality to a standard meter stick kept in Paris. What makes this table a meter in length is not its conformity to a Platonic essence but its conformity to a concretely existing individual. Similarly, on my present suggestion, what most ultimately makes an act of love a good thing is not its conformity to some general principle but its conformity to, or imitation of, God, who is both the ultimate source of the existence of things and the supreme standard by which they are to be assessed. ${ }^{17}$

To imagine the Paris meter bar as a particularist paradigm, we shall have to re-imagine its history to some extent. (And in the above quote, Alston seems to realize that treating the Paris meter bar as a genuine particularist example requires some fictionalization.) In real history, there was already a definition of the meter, and the meter bar was made in accordance with this definition. Thus, the meter bar was produced with the intention that it be precisely 1 meter long. Thus, real history causes the meter bar to diverge from Alston's model of God, because the meter bar isn't really a particularist model: it violates the requirement of the particularist model that the paradigm be the standard, instead of conforming to an external standard.

Let us suppose, then, that the meter bar really does match Alston's particularist model. Let us suppose that there was no external standard of metric length prior to the creation of the meter bar, and that the meter bar really did establish, for the first time ever, the length of the meter,

\footnotetext{
${ }^{16}$ Alston (2002), p. 292.

${ }^{17}$ Alston (2002), p. 292.
} 
and that the length of the meter was determined only by reference to this particular entity, the meter bar. Now this model fits Alston's particularism: it is truly accurate to say that anything that is (or approximates) a meter is so purely in virtue of resembling the meter bar, and not in virtue of matching any pre-existing standard independent of the meter bar. It is a genuine particularist model, on our retelling of history. (And I think that something like this retelling is what Alston intends when he prefaces his discussion of the Paris meter bar with the phrase "Let's say that....)

Now consider an object - say, a piece of wood. This piece of wood has a particular length, L. Suppose this length, L, is the same length as that of the Paris meter bar. Thus, $\mathrm{L}$ is 1 meter. Which of the following claims is true?

(1) This particular length, $L$, is 1 meter because the Paris meter bar has this particular length.

(2) The Paris meter bar is 1 meter because it is this particular length, $\mathrm{L}$.

If the Paris meter bar is a genuine particularist standard, (1) is true and (2) is false. As Alston writes, "What makes a certain length a meter is its equality to a standard meter stick kept in Paris." ${ }^{18}$ (2) must be rejected for multiple reasons, not the least because it smacks of the Platonism rejected by Alston - "What makes this table a meter in length is not its conformity to a Platonic essence but its conformity to a concretely existing individual." ${ }^{19}$ But more importantly, (2) reverses the order of explanation - the measurement of the meter bar isn't fixed by comparison with some abstract length, or by comparison with some external standard. Rather, the meter bar is the standard which determines the unit of measure for $\mathrm{L}$ and other lengths. That is how a particularist model works. So understanding the Paris meter bar as a particularist example, (1) is true and (2) is false.

But understanding particularist examples like the Paris meter bar sheds light on Alston's particularist model of goodness. For sentences precisely parallel to (1) and (2) can also be constructed with respect to God, goodness, and the virtues:

(3) These particular virtues (lovingness, mercy, etc.) are good because God possesses these particular virtues.

(4) God is good because God possesses these particular virtues (lovingness, mercy, etc.)

${ }^{18}$ Alston (2002), p. 292.

${ }^{19}$ Alston (2002), p. 292. 
(3) and (4) are precisely parallel in structure to (1) and (2) ${ }^{20}$; and with the particularist example of the Paris meter bar, (1) is true and (2) is false. (2) is false because with particularism, the order of explanation goes in a particular direction: from the exemplar toward the traits the exemplar is established to exemplify. The order of explanation does not reverse; if it does, you are not a particularist. This strongly suggests that if we construe God as a particularist paradigm, as Alston intends, we should likewise find (3) to be true and (4) to be false.

The Paris meter bar example reveals something about particularism. With particularism, the order of explanation goes one way: it goes from the exemplar to the specific traits it possesses, conferring some status on them. The meter bar confers meter-hood on its specific length; that is its job as the particularist model of the meter. The order of explanation does not reverse: meter-ness, as a Platonic entity or independently-defined length, does not define the meter bar as being a meter long. Similarly, God defines the virtues as good, by being the particularist model of goodness. The virtues do not confer goodness on God, any more than a meter length confers meter-hood on the meter bar.

Let us apply this lesson to the theory endorsed by Alston, Adams, Craig and company. We have seen that it is the function of particularist exemplars to have a particular logical priority, a particular order of explanation. The meter bar exists to confer 'meter-hood' on particular lengths. Lengths do not confer meter-hood on the meter bar; that would reverse the order of explanation and violate particularism by implying a standard prior to the meter bar for judging lengths. Similarly, if God is to serve as a particularist exemplar, He must confer goodness on the virtues. The virtues cannot confer goodness on him, cannot explain wherein God's goodness consists. For to say that God is good because

\footnotetext{
${ }^{20}$ We can show that 1 and 3 have exactly the same structure: $A$ is $B$ because $C$ has the same $A$ (with the implication that the explanation is provided by the fact that $C$ is $B$ ). Substituting terms for variables A, B and C, 1 becomes:

This length is 1 meter because the meter bar has this length (and the meter bar is 1 meter).

3 becomes:

Virtues (like kindness) are good because God has the same virtues (and God is good).

The parallel structure of 2 and 4 can also be shown: $C$ is $B$ because it has $A$ (with the implication that the explanation is provided by the fact that $A$ is $B$ ). Again, substituting for variables, 2 becomes:

The meter bar is 1 meter because it is this length (and this length is 1 meter) 4 becomes:

God is good because he has virtues like kindness (and the virtues are themselves good).
} 
he possesses these virtues, or that God's goodness supervenes on these virtues, is to reject particularism in favour of some theory that locates the source of moral value outside of God. Wes Morriston has recognized this point:

Is God good because He has these good-making properties?...If this is the right way to look at the matter, then moral goodness supervenes directly on the good-making properties, and it makes not the slightest difference to their good-makingness who has them. A person is morally good to the degree that she possesses these properties. That goes for God as much as for anyone else. But then we are right back in the box we were trying to get out of. God is subject to an independent standard of goodness... ${ }^{21}$

Alston cannot consistently maintain that "God is good by virtue of being loving, just, merciful and so on"22 and be a particularist. If he wants to be a particularist, the order of explanation can only go in one direction: the character traits like being loving, just and merciful are virtues - are good - just because they are possessed by God.

There are other ways of seeing how on Alston's view, God's goodness must be logically prior to the goodness of the particular moral virtues. That this is so can be seen by looking at another objection to Alston's account raised by Morriston. Morriston writes,

Alston's point...is that explanation must come to an end somewhere. Whatever our ultimate standard is - whether it is an individual paradigm or a general principle of the sort favored by Platonists - that is as far as we can go. If Alston cannot say what makes goodness supervene on God's characteristics, neither can the Platonist say what makes it supervene on a bunch of properties. In either case, it just does supervene, and that is all there is to say. But even if this is right, we can still ask which stopping point is preferable. If we have to stop somewhere, why not stop with the special combination of love and justice that make up God's moral character? Why go further and insist that goodness supervenes on these characteristics only because they are characteristics of the particular individual who is God? From the point of view of moral theory, it is hard to see any real advantage in doing this; it complicates things considerably, and the theological window-dressing seems quite superfluous. ${ }^{23}$

\footnotetext{
${ }^{21}$ Morriston (2009), p. 253.

${ }^{22}$ Alston (2002), p. 292.

${ }^{23}$ Morriston (2001), p. 132.
} 
Of course, Adams' and Alston's answer to Morriston's hypothetical question ("Why not stop with the special combination of love and justice...?") must be that if these were not characteristics of God, they wouldn't be virtues - they wouldn't be good. Recall our discussion of Adams' theory of the semantics of 'good' - for Adams, in a world without God, there might be traits such as lovingness and justice, but they wouldn't be good, per se. As Wainwright commented, assuming that "Adams's account of the semantics of 'good' is more or less correct, then the term 'good' doesn't pick out a real property in those worlds; the concept of good will be as empty in those worlds as the concept of phlogiston is in ours." ${ }^{24}$ Alston, as we have seen, seems to make a similar claim, writing,

Lovingness is good (is a good-making feature, that on which goodness is supervenient) not because of the Platonic existence of a general principle or fact to the effect that lovingness is good, but because God, the supreme standard of goodness, is loving. Goodness supervenes on every feature of God, not because some general principles are true but just because they are features of God. ${ }^{25}$

Notice the crucial phrases: 'because ... just because...". The clear implication is that the virtues are virtues - are good - just because there is a God who exemplifies these traits. These traits have no independent power to impart goodness on something. If there were no God, and someone were loving, merciful, and so forth, then that person (on the Adams/Alston view) would not be good. Thus, God's goodness is logically prior to the goodness of these traits - these traits are not intrinsically good (for without God, they are not good). God is good, and in virtue of God's possession of these traits, they too are good. We see, then, that God cannot be good in virtue of these traits, because God's goodness must be logically prior to the goodness of these traits. So with this in mind, let us recall Alston's quote, cited earlier:

Note that on this view we are not debarred from saying what is supremely good about God. God is not good, qua bare particular or undifferentiated thisness. God is good by virtue of being loving, just, merciful and so on. ${ }^{26}$ This cannot be right. God cannot be good by virtue of possessing these traits, because these traits don't have the power to confer goodness upon God. God's goodness is logically prior to the goodness of these traits,

\footnotetext{
${ }^{24}$ Wainwright (2005), p. 95.

${ }^{25}$ Alston (2002), pp. 291-2, emphasis added.

${ }^{26}$ Alston (2002), p. 292.
} 
so logically speaking God's goodness comes first, and then comes the goodness of these traits. You cannot explain God's goodness in terms of His being "loving, just, merciful, and so on," because the goodness of these traits is logically subsequent to God's goodness, and is to be explained in terms of the latter property.

\section{THE INCOHERENCE OF ALSTON'S VIEW}

I conclude that God's goodness cannot be explained in terms of the goodness of the concrete virtues. We cannot say that God is good because He is loving, merciful, just and so on. Again, this violates our normal understanding of thin moral concepts: agents are not good simpliciter, but are good because they embody thick moral concepts, like lovingness and justice. But the particularism defended by Alston prevents him from explaining God's goodness in this way, and saddles him with a notion of divine goodness that is empty of content.

How can Alston reply? Perhaps one can argue that we can say something about even such a stripped down property: we can say (with Aquinas) that "the essence of goodness consists in this, that it is in some way desirable". ${ }^{27}$ The problem is that God's goodness, understood in the minimalist way outlined above, is a total blank, stripped of any feature that would make intelligible why it is desirable or worthy of pursuit.

The essential problem in the Adams/Alston view can be brought into sharp relief by discussing another objection addressed by Alston. Speaking for his opponent, Alston writes, "Isn't it arbitrary to take some particular individual, even the supreme individual, as the standard of goodness, regardless of whether this individual conforms to general principles of goodness or not?"28 In response to this objection, Alston writes,

An answer to the question, 'What is good about?' will, sooner or later, cite certain good-making characteristics. We can then ask why we should suppose that good supervenes on those characteristics. In answer either a general principle or an individual paradigm is cited. But whichever it is, that is the end of the line... On both views something is taken to be ultimate, behind which we cannot go, in the sense of finding some explanation of the fact that it is constitutive of goodness. ${ }^{29}$

${ }^{27}$ Aquinas, Summa Theologica Ia.5.1. Quoted in Wierenga (1989), p. 202. As Wierenga notes, though, Aquinas is not talking specifically about moral goodness here.

${ }^{28}$ Alston (2002), p. 293.

${ }^{29}$ Alston (200), p. 293. 
There are a few comments that need to be made at this point. First, Alston is making a familiar point about explanatory regress, and solving it in a familiar way: eventually, you reach a stopping point in the regress of explanations, and some principle or exemplar must be taken as ultimate. While this may, in some instances, be an acceptable move, it is not acceptable in all cases. One's stopping point must be intelligible as a stopping point. For example, when Aristotle conducts his familiar inquiry into the ultimate telos of all human action, the stopping point he finds - eudaimonia, happiness, or flourishing - is intelligible as a stopping point for such an inquiry. It has features that make sense of it as a goal of human striving. But, as we have already seen, God is not morally good in virtue of any of the familiar characteristics (such as being just or loving). God's moral goodness is utterly blank, without any features that make it intelligible as a stopping place in an inquiry into the ultimate foundation of goodness. Since Alston and Adams make God's goodness prior to any of God's concrete moral virtues, the person of God is not intelligible as a stopping place in the quest for the ultimate source of good. God's supposed goodness, as I said above, is a complete blank, lacking any features whatsoever that would make it intuitively appealing why the object in question should be regarded as the ultimate exemplar of moral goodness. ${ }^{30}$

Alston writes that it is 'self-evident' that God is the ultimate exemplar of moral goodness, and a legitimate stopping place:

I would invite one who finds the invocation of God as the supreme standard arbitrary, to explain why it is more arbitrary than the invocation of a supreme general principle. Perhaps it is because it seems self-evident to him that the principle is true. But it seems self-evident to some that God is the supreme standard. And just as my opponent will explain the lack of self-evidence to some people of this general principle by saying that they have not considered it sufficiently, in an impartial frame of mind or whatever, so the theistic particularist will maintain that those who don't acknowledge God as the supreme standard are insufficiently acquainted with God, or have not sufficiently considered the matter. ${ }^{31}$

In our regress of justification, we ultimately encounter some principle or exemplar, and the truth of this principle (or the exemplariness of this

\footnotetext{
${ }^{30}$ We have seen above, in the second lengthy quote by Morriston, how he criticizes Alston's choice of stopping places in the regress of explanations.

${ }^{31}$ Alston (2002), p. 293.
} 
exemplar) is self-evident or known via intuition. Once again, our question must be, 'Is this plausible?' Alston implies that one who is sufficiently acquainted with God and who has given the matter adequate, impartial thought will come to see (with justification or warrant) that God is the standard of moral perfection. But we can now see why this is wrong. For when one imagines acquaintance with God, and contemplation of the divine, one naturally imagines contemplating God given his attributes such as being perfectly loving, just, merciful, and so forth. And of course someone who contemplated God as so presented might well come to believe in God's moral perfection. But Alston must claim that God is the standard of moral perfection independently of his possession of these characteristics. He is not morally perfect because he possesses these characteristics; these characteristics are features of moral perfection only because they are possessed by God. Thus, what Alston should exhort us to do is this: imagine God, stripped of every moral perfection - His lovingness, His justice, His caring. Now is it self-evident that God as so conceived is morally perfect, the ultimate standard of good? Intuition is not a magical power; it needs something to work with. If intuition is a genuine mental power (and presumably, if it is, it is the power of forming non-inferential beliefs in response to some stimulus or mental input), then intuition requires inputs to generate an output. When Alston tells us that God's moral perfection is self-evident, he is imagining God's moral virtues as cognitive inputs, in which case we should expect as an output the belief "God is the standard of goodness". But the question must be reconceived: 'Does it make sense to say of God, independent of these virtues, that He is good?' I have argued this is not coherent; it is certainly not self-evident that God so conceived is the ultimate standard of moral perfection.

Anyhow, this discussion of self-evidence may mislead us: the problem we are dealing with is metaphysical, not epistemological. Alston presents the regress problem almost as an epistemological problem: how do we identify the ultimate source of good? If we have some knowledge of what traits (such as being loving and just) are good, then (plausibly) we need only find the being who exemplifies these traits to the maximal degree to find the exemplar of the good. But the problem we are grappling with is metaphysical, not epistemological: we are not (merely) trying to identify the source of good; we are trying to explain how it confers goodness on all things. So we cannot help ourselves to these virtuous traits (even if we know they are virtuous), because our problem is to explain how they are 
virtuous, not merely to identify which being is most virtuous. We must consider the source of these traits' goodness (God), and ask, "How is it that this being confers goodness on these traits?" Alston, Adams, Craig and others answer, "In virtue of being supremely good." But once we confine ourselves to a strictly metaphysical investigation, we see that this statement is meaningless, because we are debarred from appealing to any features of God which might make His goodness coherent, or explain why His goodness is worthy of admiration or capable of conferring praiseworthiness on the traits (such as lovingness and justice) that He possesses.

I said when we began our discussion of the regress of explanations that a few comments were in order. Here is another: we must distinguish between explanations-why and explanations-what. Even if explanationswhy come to an end, and no further reasons can be given at this point, it does not follow that at this point there can be no further explanationwhat. For we should still be able to explain what something is even if we can give no further explanation for why it is the way that it is. For example: suppose (contrary to fact) that the electron's negative charge were simply a brute fact, and that no explanation could be given for why electrons have a negative charge. This would be an example of running to the end of explanations for why things are the way they are. But we could still give an explanation of what a negative charge is: how it interacts with positively-charged items (like protons), what the strength of its electrical charge is, and so forth. So even if we can say nothing about why the electron has this charge, we can say quite a lot about what this charge is.

To deny this with respect to God's goodness is to conflate the two types of explanation, explanations why and explanations what. (This confusion is, I think, a natural consequence of confusing the epistemological and the metaphysical.) The particularist says, in explaining why certain things are good, that at some point these why-explanations run out when we arrive at the exemplar of God's character. But this does not entail the absence of any what-explanations, and we should still be able to say what God's moral goodness consists in. But the particularist has debarred us from doing this: since God's goodness is prior to any feature we could cite in an explanation (what) of God's goodness, we cannot say what God's goodness is. It is, again, a featureless property. The particularist is not just saying that there is an end to why-explanations; she is saying that no what-explanation can be given either. And that is simply not plausible, since this makes God's goodness completely unintelligible. 
One might argue that one can give some sort of what-explanation about God's goodness. If Adams et al cannot explain God's goodness in terms of concrete virtues (such as lovingness, mercy and justice), perhaps they can attempt to explain this goodness without reference to these virtues. That is, instead of giving the explanation in terms of morally thick virtues (such as mercy, justice, kindness, etc.), they can give the explanation at the more abstract level of morally thin virtues (such as 'morally good'). As the description in question couldn't make reference to the specific thick virtues, this description would of necessity have to be somewhat general in nature. But it might nevertheless be a satisfactory what-explanation. Can you say anything substantive about the morally thin virtues that doesn't rely, even implicitly, on the morally thick virtues?

Perhaps one could say that God's goodness consisted of God always doing what was right. This won't work, though, as theological voluntarists have specifically bifurcated their moral theory to respond to the original Euthyphro problem for divine command theory: there is a theory of the good for God, and a theory of obligation for finite beings like humans. More importantly, though, good must be definable antecedent to right (since it is God's goodness that gives God reason to issue the particular commands that He does). Thus, on this view, good is logically prior to the right, and so it must be possible to give a definition of 'good' that makes no reference to rightness, obligation, or other cognate notions.

One cannot say that God's goodness consists in that He always does the good, for not only is that definition circular, but it uses a predicate (good) that we are already complaining is undefined.

Consider again Aquinas' suggestion: "the essence of goodness consists in this, that it is in some way desirable." ${ }^{32}$ However, as Scanlon ${ }^{33}$ and Quinn ${ }^{34}$ have argued, something is desirable not because you desire it, but because it has features that render it desirable - that is, in some way good. Now, there is a clear risk of circularity here - "the essence of goodness consists in this, that it is in some way good" - so to render our formulation non-circular, we must specify the precise ways in which God is good: we must specify the features of God that render Him desirable, good. But if there were specific features of God, in virtue of

\footnotetext{
${ }^{32}$ Aquinas, Summa Theologica Ia.5.1. Quoted in Wierenga (1989), p. 202.

${ }^{33}$ See Scanlon 1998, particularly pp. 43ff.

${ }^{34}$ Quinn (1993), chapter 12.
} 
which He was good, then we would be thrown back on the first horn of our dilemma: God is good in virtue of certain features (and hence there is a standard of goodness independent of God).

Indeed, the whole problem of trying to move the explanations-what up to the level of thin virtues must fail. As I have repeatedly emphasized, agents instantiate morally thin properties (such as goodness) in virtue of the morally thick properties these agents instantiate. Alston's particularism cannot countenance this fact, and so must fail as a supplement to the divine command theory.

In a last-ditch move, one might cite authors (like G.E. Moore) who have argued that the Good is unanalyzable. But even if Moore was right, he merely meant that one could not analytically reduce the Good to other non-normative or non-moral concepts. So, when Moore argued that the Good was unanalyzable, he simply meant that it was not definitionally reducible; he didn't mean that it was inexplicable. So the divine command theorist will find no comfort coming from that quarter.

Thus, Alston must commit to one or the other horn of the dilemma. His particularism commits him to the second horn of the dilemma. In short, Alston must answer the question, "Why is being loving good?" by saying, "Traits (like being loving) are good-making because God has them, and God is good." But on Alston's particularism, when we say "God is good", we haven't said anything, because Alston's particularism prevents him from giving any concrete articulation of what goodness is. Unfortunately, on the particularist theory, we have no more (or less) reason to declare God essentially good than to declare Him essentially fnord or bxtzs; for by calling God 'good' we haven't really said anything at all.

\section{CONCLUSION}

Adams writes that "the part played by God in my account of the nature of the good is similar to the Form of the Beautiful or the Good in Plato's Symposium and Republic. God is the supreme Good, and the goodness of other things consists in a sort of resemblance to God." ${ }^{35}$ In a similar vein, Alston writes, "I want to suggest...that we can think of God himself, the individual being, as the supreme standard of goodness. God plays the role in evaluation that is more usually assigned, by objectivists about

\footnotetext{
${ }^{35}$ Adams (1999), p. 7.
} 
value, to Platonic Ideas or principles." ${ }^{36}$ But as we have seen, since Adams and Alston are forced to make the goodness of God logically prior to any of the traits that might plausibly constitute God's goodness, it is not at all clear what is meant by the claim that God is the standard of goodness, for the simple reason that it is not clear what is meant by the claim that God is good. To make any sense of the claim that God is good, the traits constitutive of goodness (such as being loving) must be good prior to God's goodness: it must be the case that God is good because he is loving, and not the case that being loving is good because God is loving. But this requires a repudiation of the particularism that is at the heart of views like Adams' and Alston's. This would also require a standard of moral goodness that is independent of God's nature. One could make it dependent on God's will or commandments or decisions, but of course that throws us back in the original arbitrariness problem. Thus, it seems as though an adequate solution to the Euthyphro problem requires that God be constrained by standards of moral goodness that are external to Himself. ${ }^{37}$ Perhaps this creates problems for divine sovereignty and the like, but that is separate problem. ${ }^{38}$

\section{BIBLIOGRAPHY}

Adams, Robert Merrihew. 1999. Finite and Infinite Goods: A Framework for Ethics (New York: Oxford University Press)

Alston, William P. 2002. "What Euthyphro Should Have Said", in William Laine Craig (ed.), Philosophy of Religion: A Reader and Guide (Rutgers University Press), pp. 283-298

Elstein, Daniel Y. and Thomas Hurka. 2009. "From Thick to Thin: Two Moral Reduction Plans", Canadian Journal of Philosophy 39:4 (December)

Hooker, Brad. 2001. "Cudworth and Quinn", Analysis 64:1, pp. 333-335

Kowalski, Dean A. forthcoming. "Remembering Alston's 'Evaluative Particularism"', Religious Studies

${ }^{36}$ Alston (2002), p. 291.

${ }^{37}$ An alternate solution to the Euthyphro problem is proposed in Chapter 2 of Stump (2003). This solution requires embracing some potentially contentious notions, such as that of divine simplicity and the Thomistic idea that being is identical to goodness. To address these issues is unfortunately beyond the scope of the current essay.

${ }^{38} \mathrm{I}$ am grateful to an anonymous referee for the European Journal for Philosophy of Religion for very helpful feedback on an earlier draft. 
Morriston, Wes. 2001. "Must There Be a Standard of Moral Goodness Apart from God?", Philosophia Christi, Series 2, 3:1, pp. 127-138 - 2009. "What if God Commanded Something Terrible?”, Religious Studies 45:3, pp. 249-267 Quinn, Philip L. 2006. "Theological Voluntarism", in David Copp (ed.), The Oxford Handbook of Ethical Theory (Oxford: Oxford University Press), pp. 63-90

Quinn, Warren S. 1993. Morality and Action (Cambridge: Cambridge University Press)

Scanlon, T.M. 1998. What We Owe to Each Other (Cambridge, MA: Harvard University Press)

Stump, Eleonore. 2003. Aquinas (New York: Routledge)

Wainwright, William J. 2005. Religion and Morality (Aldershot: Ashgate)

Wierenga, Edward R. 1989. The Nature of God: An Inquiry into Divine Attributes (Ithaca, New York: Cornell University Press) 